Article

\title{
The Story of Journalist Organizations in Czechoslovakia
}

\author{
Markéta Ševčíková ${ }^{1, *}$ and Kaarle Nordenstreng ${ }^{2}$ \\ ${ }^{1}$ Independent Researcher, Prague, Czech Republic; E-Mail: sevcikova.m@post.cz \\ 2 Faculty of Communication Sciences, University of Tampere, 33014 Tampere, Finland; \\ E-Mail: kaarle.nordenstreng@uta.fi \\ * Corresponding author
}

Submitted: 15 May 2017 | Accepted: 23 August 2017 | Published: 27 September 2017

\begin{abstract}
This article reviews the political history of Czechoslovakia as a vital part of the Soviet-dominated "Communist bloc" and its repercussions for the journalist associations based in the country. Following an eventful history since 1918, Czechoslovakia changed in 1948 from a liberal democracy into a Communist regime. This had significant consequences for journalists and their national union and also for the International Organization of Journalists (IOJ), which had just established its headquarters in Prague. The second historical event to shake the political system was the "Prague Spring" of 1968 and its aftermath among journalists and their unions. The third landmark was the "Velvet Revolution" of 1989, which played a significant part in the fall of Communism in Central and Eastern Europe and led to the closing of the old Union of Journalists in 1990, followed by the founding of a new Syndicate which refused to serve as the host of the IOJ. This led to a gradual disintegration and the closing down of what in the 1980s was the world's largest non-governmental organization in the media field.
\end{abstract}

\section{Keywords}

Cold War; communism; Czechoslovakia; International Organization of Journalists; journalism; union of journalists

\section{Issue}

This article is part of the issue "Histories of Collaboration and Dissent: Journalists' Associations Squeezed by Political System Changes", edited by Epp Lauk (University of Jyväskylä, Finland) and Kaarle Nordenstreng (University of Tampere, Finland).

(C) 2017 by the authors; licensee Cogitatio (Lisbon, Portugal). This article is licensed under a Creative Commons Attribution 4.0 International License (CC BY).

\section{Introduction}

The starting point of this article is a story about the rise and fall of the IOJ-an international non-governmental organization of journalists based in Czechoslovakia, which had become an icon of the changing political landscape of the world since 1946 . The same story has been told in an anthology of the history of the international movement of journalists (Nordernstreng, Björk, Beyersdorf, Høyer, \& Lauk, 2016) and also in a monograph on the IOJ (Nordenstreng, in press), but this was done without covering the broader context of the political history of Czechoslovakia. The present review aims to fill the gap by first describing the key political turns in the history of Czechoslovakia since World War I (Emmert, 2012).

\section{Political History of Czechoslovakia from 1918 to the 1990s}

\subsection{Four Periods between 1918 and 1948}

If we wish to understand the events which took place in post-war Czechoslovakia, particularly in February 1948, when the Communist Party took over political power in the country, we need to go back another thirty years. Czechoslovak history divides the period between 1918 and 1948 into four main phases: the First Republic, the Second Republic, the Protectorate of Bohemia and Moravia and the Third Republic.

The period of the First Republic is defined by two dates: 28 October 1918 (birth of independent Czechoslo- 
vakia) and 30 September 1938 (signing of the Munich Agreement). In 1918 Czechoslovakia ceased to be part of the Austro-Hungarian Empire and became an independent republic with a democratic polity based on the Constitution. The country consisted of Bohemia, Moravia, Silesia, Slovakia and Subcarpathian Ruthenia. The Republic was characteristically multi-ethnic and there were initially large social, cultural and economic differences between its individual regions. The internal unity of the new state was challenged by the German ethnic minority living in the border regions and wishing to become part of Germany, and the leftist labour movement, which founded the Communist Party of Czechoslovakia (henceforward the CPC) in May 1924. In the short term, however, Czechoslovakia became a mature democratic republic with a broad spectrum of political parties, and the republic advanced in leaps and bounds in the fields of industry, trade, education and lifestyle. An extensive print media developed, the press being primarily partisan, with a minority non-party press, tabloids and magazines, and the new media of radio and film were evolving. Partial censorship existed and was carried out by the Ministry of Interior. Publishers had to submit mandatory copies to district authorities or police headquarters, who had the right to withhold prints prior to their release, to allow the issue only after a change or deletion of the text or even confiscate the press (Končelík, Večeřa, \& Orság, 2010). Nevertheless, cultural openness and tolerance prevailed.

The next period of the Second Republic began with the signing of the Munich Agreement and the creation of the Protectorate of Bohemia and Moravia on 30 September 1938, lasting only until 15 March 1939. In this short period, Czechoslovakia lost extensive border territories, Slovakia, and Subcarpathian Ruthenia. Politically, the country was subverted and the democratic principles of the First Republic, organization and freedom were destroyed. The Party of National Unity and the National Labour Party became the only two political parties. ${ }^{1}$ Czechoslovak society perceived the Munich Agreement as a defeat which threw it into disillusion and moral crisis. These facts were also reflected in the media, with the disappearance of many periodicals and the intensification of censorship.

The third period between 16 March 1939 and 8 May 1945 is known as the Protectorate of Bohemia and Moravia. The territory of the Protectorate included practically all of the present-day Czech Republic, so Nazi Ger- many effectively occupied the entire country. The Czech president formally remained Head of the Protectorate, along with the Protectorate's Czech government. Nevertheless, the real power-with a brutal and totalitarian Nazi regime-was held by a Reichsprotektor, who was hand-picked by Adolf Hitler. This means that the Germans had the Czech economy, industrial and agricultural production, transport, education and culture fully under their control. The media were controlled by a Nazi information monopoly and subjected to severe censorship. In addition to the official media, illegal and media in-exile were quickly established. The Czech population was subjected to a programme of Germanisation. Citizens of Jewish origin were deprived of their civil rights, persecuted in various ways, including the confiscation of property, and, starting in the autumn of 1941, were gradually physically eliminated.

Understandably, the Czech people did not accept the occupation and resistance to it soon emerged. These activities culminated in the assassination of the Reichsprotektor. Meanwhile, the government-in-exile, led by Edvard Beneš, was established in London. Any expressions of anti-Nazi feeling were brutally suppressed by the occupiers-punished by death, imprisonment or detention in a concentration camp. Nevertheless, a number of Czechs cooperated-collaborated-with the occupying regime during the Protectorate. However, the majority of the population continued to oppose the Germans (Emmert, 2012) and, on 5 May 1945, resistance to the occupation developed into an armed Prague uprising, ${ }^{2}$ which ended on 8 May 1945 with the defeat of Germany.

Finally, the fourth period from the May 1945 to February 1948 is called the Third Republic. The basic document establishing the direction of Czechoslovakia after World War II was the Košice Government Programme, ${ }^{3}$ which introduced the first post-war Czechoslovak Government heavily influenced by the USSR - the winner of the war. It was drawn up by the Moscow-based leadership of the $\mathrm{CPC}$ and proclaimed the confiscation of property belonging to Germans, Hungarians and Czech collaborators, the punishment of collaborators, an equal relationship between Czechs and Slovaks, the establishment of National Committees ${ }^{4}$ and fundamental changes in the economic and social spheres, as well as the banning of the activities of right-wing political parties. Accordingly, it not only dealt with the punishment of war criminals, traitors and collaborators, but also led to the rejection of the First Republic's political and economic system. Some Czech

\footnotetext{
${ }^{1}$ The political system of the Second Republic was simplified and there were only two main political parties: (1) an "official" right-wing Party of National Unity (Strana národní jednoty) gathering together the Republican Party of Farmers and Peasants, Czechoslovak Traders' Party, National Fascist Community, Czechoslovak Christian Social Party, National People's Party, and (2) in "loyal" opposition, the left-wing National Labour Party (Národní strana práce).

2 The Prague uprising was an attempt by the Czech resistance to liberate the city of Prague from German occupying forces. It lasted from 5 May until 8 May 1945, ending in a ceasefire between the Czech resistance and the German army, which decided to leave Prague on the same day. Next morning, the Red Army entered the nearly liberated city.

${ }^{3}$ See an educational portal for teachers, students and pupils available on the internet http://www.moderni-dejiny.cz/clanek/kosicky-vladni-program-54-1945

${ }^{4}$ The National Committee (1945-1990; NC) was a part of the Czechoslovak state administration with formally elected bodies. The NC was divided according to the place of operation-from the top level of the country, within regions, districts and towns to municipalities. It performed as an "extended arm" of the CPC for the economy and whole society.
} 
historians view this part of Czechoslovak history in two ways: either as a short period of freedom squeezed in between two dictatorships (Nazi and Communist) or as the trappings of democracy leading to the Communist snare. (Drápala, 2000)

In May 1946 Czechoslovakia held its first post-war parliamentary elections. A limited number of parties participated in the election. While the CPC won in the Czech lands with more than $40 \%$ of the vote, the Democratic Party won in Slovakia with $60 \%$ of the vote. In June 1946, the pre-war leader Edvard Beneš was confirmed as President of the Republic, and he appointed a government led by CPC chairman Klement Gottwald. In October 1946, the Czechoslovak National Assembly approved an economic plan for the reconstruction of post-war Czechoslovakia.

In 1947 the USSR began to create the Eastern bloc by arrangements such as a peace treaty concluded with Hungary and a friendship and mutual assistance treaty concluded with Poland. At this time Czechoslovakia followed Moscow's "advice" to withdraw from the Marshall Plan and to sign a trade agreement with the USSR.

In the post-war atmosphere the liberalism and humanism which characterized the First Republic were perceived by the majority of society as the root of all evil, which was to blame for the hardships of war, human degradation and the total collapse of modern society. The central theme of the time was socialism, which was also complemented by nationalism and Slavonic patriotism. In May 1945 the Ministry of Information issued a Decree forbidding the publication of any printed material, with the exception of selected dailies issued by $\mathrm{Na}$ tional Front parties. Further permission to publish was only granted to those organisations which could prove that this was in the public interest.

In the Third Republic immediately after the war, the Czechoslovak press was made up of three ideologicalpolitical types: (1) the Communist press and periodicals with Communist sympathies, (2) a democratic leftwing press and (3) the non-Socialist press. Censorship was not exercised, although the press laws dating back to the First Republic provided for it. But the situation changed in autumn 1947, when the Communists began to perceive censorship as an indispensable instrument of power. In December 1947 the Ministry of Information created the Surveillance Department, which aimed to monitor objectionable texts dealing with the national economic plan, incitement against the Slavonic peoples as well as deviation from the basic line in domestic and foreign policy and matters connected to the defence of the state (Kaplan \& Tomášek, 1994).

\subsection{The Communist Takeover of 1948}

A dramatic government crisis started in Prague on 13 February 1948 when personnel changes in favour of the Communists were made in the National Security Corps. The response to the ever-increasing influence of the CPC was the resignation of the non-Communist ministers, 12 members of a 26-member government, on 20 February 1948. The CPC and groups sympathetic to it within individual parties began to establish the National Front Action Committees (NFAC), whose aim was to "cleanse" the government and public life of all non-Communist political forces. Two days later, the People's Militia also came into being, armed units consisting mostly of workers directly controlled by the CPC. Their main aim was the defence of industrial enterprises and the intimidation of their political (anti-Socialist) opponents. The conflict continued on 24 February 1948 with an hour-long general strike in support of the CPC's requirements, and escalated on 25 February, when President Edvard Beneš agreed to make changes in the government as suggested by Klement Gottwald.

This is how Communists came to power in Czechoslovakia-widely known as the "Communist coup". In early May, a new Constitution was approved, and the definitive influence of the CPC in the country was formally confirmed on 30 May 1948 by the parliamentary elections. All the parties stood on a single list of candidates led by the CPC and $89 \%$ of the electorate voted for them. $70 \%$ of members of the National Assembly were Communists, and the remaining members from other parties were proCommunist. Finally, in June 1948, Klement Gottwald became the new President.

At this stage the CPC brought society under totalitarian control. The economy was based on the principle of central planning, and companies with more than 50 employees were nationalised. Under pressure from Moscow, the CPC's Central Committee began to take a hard line against any criticism of the Communist system or in favour of liberal thinking. There were a number of fabricated political trials, forced labour camps were created and the strict supervision of the censor covered not only the field of culture, including the press, but also the life of the Church. A counter-reaction to the situation was a wave of emigration, during which a large community of post-February 1948 emigrants founded publications in exile. May 1951 saw the launch of Radio Free Europe with regular broadcasts from Munich.

After February 1948 the CPC began to introduce censorship which would apply not only to the periodical and non-periodical press, radio, film and the early days of TV, but also to exhibitions, libraries, local records, posters, advertising leaflets, badges, labels and the like. In this way, the media became closely intertwined with the system of political power, while the limits of journalistic freedom were defined by the National Front and selfcensorship (Končelík et al., 2010). The system of censorship policed the flow of information both at home and abroad. There was a ban on importing foreign newspapers and magazines, press agencies were shut down, as were cultural centres and information offices with their headquarters in the West. The state security routinely monitored correspondence sent from and to capitalist countries and so on. In the coming years, everything that did not suit the official ideas of the socialist press grad- 
ually disappeared from the newspapers, while the censor intervened not only in matters of content, but also of form, and tried to influence production, print run and scope. In this way, the Communist regime gained a total information monopoly.

However, in the early 1950s, a more moderate cultural policy was promoted. The reason for this was not only the fact the Soviet ideas of socialist art had proved problematic, but it was also a response to the growing conflict within the CPC itself (Knapík, 2006). The concept of the "new course" ${ }^{5}$ opened up the possibility of liberalisation in Czechoslovakia's cultural sphere between 1953 and 1956. After the death of Josef Stalin in 1953 and the criticism by Nikita Khrushchev in 1956, the regime began to look more kindly on some still-rejected personalities, less strict aesthetic criteria appeared, and even some channels for contact with the West were introduced. A new artistic generation began to take shape that did not feel itself as bound to the dogmatic doctrines of the late 1940s and early 1950s. While the Cold War continued as an overall frame, it was possible to hope for the promotion of liberalistic tendencies.

The pressure for reforms in the CPC and other aspects of everyday life increased after the mid-1960s. As the reform supporters became increasingly recognized in the CPC and public life, the liberal orientation in the country and in the CPC gradually won the support of the majority for a revised form of Communism.

\subsection{The Prague Spring of 1968}

In 1968 the world was in turmoil, with the war in Vietnam, the civil rights movement in the USA and student unrest throughout Europe, especially in France. It was a unique year in post-war history, as 1848 had been a hundred years earlier. And the "Prague Spring" became its focal point.

For a short period, from January to August 1968, there was a huge development among politicians, intellectuals, students and ordinary public life spheres in Czechoslovakia. The social and political criticism of the system had been gradual and fundamental and was reflected in economy, central management, culture and media. At the end of 1967 a crisis in the CPC itself deepened and the party split into two groups: (1) conservatives, represented by Antonín Novotný, Czechoslovak president and CPC first secretary, and (2) reform Communists, who wanted to democratize the old politics. In January 1968 the big break happened, when Antonín Novotný was removed as first secretary of the CPC and replaced by Alexander Dubček, a reform Communist from Slovakia.

The motto of Dubček's new political programme was "Socialism with a human face". Although the Czechoslovak economy should still be based on state or co-operative ownership, non-Communist parties, broad public community and free elections should also be involved in political power. Admission to leading positions and universities should no longer be contingent upon CPC membership. The reforms also abolished censorship and an informal alliance developed between Dubček's leadership and journalists. Indeed, the media played a crucial role in the Prague Spring (Končelík et al., 2010). Freedom of speech flourished and different associations like the scout movement were restored. The Prague Spring changes were supported throughout society and had a considerable international response.

However, the Soviet Communist Party, together with its sister parties in other Socialist countries, were afraid of this revival process, and this fear led to the occupation of Czechoslovakia by Warsaw Pact military forces on 21 August 1968. From September 1968 the so-called Moscow Protocol was implemented in Czechoslovakia. The Czechoslovak population of course protested against the occupation. The most radical act against the restoration of the Communist dictatorship was that of Jan Palach, a student of the Charles University, who burned himself to death on 16 January 1969 at the Prague's Wenceslas Square. In April 1969 Gustáv Husák became the first secretary of the Communist Party. Alexander Dubček and his closest associates were soon removed from public life and replaced by Soviet puppets. Everyone who participated in the Prague Spring or disagreed with the occupation was punished. Censorship was reinstated and thousands of books and films were banned. Many Czechs and Slovaks left the country.

The Prague Spring was consequently brought to a drastic end and replaced by a sweeping political process called "Normalization" lasting for 20 years. Officially Czechoslovakia was a faithful member of the Eastern bloc, and the CPC bureaucratic apparatus was severely controlling all aspects of life. Yet under the surface there existed an underground culture, intellectual dissent, samizdat and an exile literature. The CPC bureaucratic apparatus could no longer effectively control all areas of society. The most significant manifestation of the anti-Communist resistance was the publication of Charter 77 with its civil movement established in January 1977, led by writer and later Czechoslovak President Václav Havel and the university professor Jan Patočka.

\footnotetext{
${ }^{5}$ The "new course" (nový kurs) was proclaimed by the leadership of the CPC after the deaths of Stalin and Gottwald in 1953. Its result was a more benign approach to the middle classes; forced collectivisation in villages was temporarily halted, auxiliary technical battalions were disbanded, political trials were discontinued and the process of revising their outcomes began, etc. See http://www.edejiny.cz/obdobi-destalinizace-v-ceskoslovensku-1953\%E2\%80\%93-1960

${ }^{6}$ There were two main documents determining the Prague Spring: (1) Dubček's CPC Action programme posted on 5 April 1968, related to the politics and reform steps of CPC, and (2) the "Two thousand words" document written by Ludvík Vaculík together with leading Czech scientists, published on 27 July 1968. It was about the activation of the Czechoslovak public against the ever-evident pressure of the Soviet leadership against the reforms in the country. The manifesto was signed by hundreds of public figures and more than 120,000 citizens, which led to the persecution of many people in the period of normalization in the 1970s.
} 


\subsection{The Velvet Revolution of 1989}

The resistance to the Communist regime began to increase in the late 1980s, in connection with Mikhail Gorbachev's rise to power in the USSR and policy of perestroika and glasnost. The CPC claimed to agree with this Soviet reform policy, but this was rather lip service. Demonstrations of disagreement with the totalitarian regime proliferated, but were also severely suppressed by the security forces.

The most important actions took place on (1) 28 October 1988, the 70th anniversary of the founding of the Czechoslovak Republic, (2) 16 January 1989, the 20th anniversary of Jan Palach's suicide, and (3) 29 June 1989, the publication of "A Few Sentences", a call by dissident leaders for the release of political prisoners, open and free discussion, including thorny historical issues, and the end of censorship. ${ }^{7}$ The crucial event which precipitated the Velvet Revolution, happened on 17 November 1989 in the centre of Prague, when security police blocked and violently broke up a student procession to commemorate the 50th anniversary of the International Day of Students. The fundamental response to this armed intervention was the founding of the Civic Forum, headed by Václav Havel, to begin a dialogue with the Communist leaders. Massive demonstrations took place throughout Czechoslovakia in support of the Civic Forum, and university students went on strike.

On 24 November 1989, the CPC's secretary general Ladislav Adamec and his entire central committee withdrew. The name of the state was changed to Czecho-Slovak Federative Republic and the head of the Federal assembly became Prague Spring leader Alexander Dubček. On 29 December 1989 Václav Havel was elected as the new President. During 1990 Czechoslovakia became a federal republic and the transformation of Czechoslovak society and its economic, social and political life from Communist totalitarianism to liberal democracy could begin after long 40 years.

\section{The Journalists and Their Union 1946-1990}

After World War II, there were naturally significant changes in journalism as a profession. Before 1946 journalists were represented by the protectorate National Union of Journalists (NUJ; see more on this in Cebe, 2017, in this issue). The Czech Journalists' Union (henceforward the $\mathrm{CJU})^{8}$ came into being at a general meeting in
March 1946. On that occasion it was also agreed that professional matters should in future fall under the remit of the Revolutionary Trade Union Movement. ${ }^{9}$ The CJU represented a community of altogether about 800 journalists (Cebe, 2012). In 1947, following the Act on the Status of Editors and Journalists' Unions, two journalists' unions were formed, the Czech union (formerly CJU) and the Slovak union, while above them an umbrella organization was established, the Central Union of Czechoslovak Journalists (CUCSJ). In May 1947 the government passed the Act on the Status of Editors and Journalists' Unions. ${ }^{10}$ In fact, the CJU and CUCSJ were more a tool of the regime than a provider of benefits to journalists.

On this basis, the practice of journalism was tied to compulsory membership of the CJU, which had dire consequences for many journalists in the post-February cleansing. After February 1948, there were dynamic political and social changes. Even in the CJU action committees were founded and only those journalists who were willing to work with the newly-established regime remained members of the Union. The others were excluded from their professional organization and thereby lost all chances of working in the media. The NFAC forced more than one hundred experienced journalists to leave and consequently affected the Czechoslovak media for decades. (Cebe, 2012)

The new Communist Constitution of May 1948 had two main consequences for journalists and their union. Firstly, although the new Constitution guaranteed freedom of expression and prohibited censorship, the CPC consistently monitored all media production, making independent media in practice impossible. The journalist became a mere instrument lacking any autonomy, providing information on only politically-approved interpretations of events. The economy was only to be portrayed as flourishing, accompanied by the people's efforts to build it up. In the same way, both sports and scientific achievements were to be ascribed to the merits of the new Communist regime. The most significant instrument for controlling the media was, of course, the staffing policy, meaning that journalists were in constant fear of losing their jobs. (Končelík et al., 2010)

Secondly, a new, integrated Union of Czechoslovak Journalists (UCSJ; 1948-1972), headquartered in Prague, was founded and, within it, the National Union of Slovak Journalists, headquartered in Bratislava. The state, rather than the UCSJ, made the decisions regarding its focus, organizational structure or the exercise of the journal-

\footnotetext{
${ }^{7}$ For more, see http://old.ustrcr.cz/en/milestones-in-recent-czech-history-1938-1989

${ }^{8}$ The succession of changing union formations from 1946 to 1990: 1946-1947: Czech Journalists Union (CJU); 1947-1948: Czech Journalists Union (CJU), Slovak Journalists Union (SJU), Central Union of Czechoslovak Journalists (CUCSJ); 1948-1968: National Union of Czechoslovak Journalists (UCSJ), Union of Slovak Journalists (USJ); 1968-1972: Unions of Czech (UCJ) and Slovak (USJ) Journalists, Headquarters; 1972-1990: Czech Union of Journalists (CUJ), Slovak Union of Journalists (SUJ), National Czechoslovak Union of Journalists (NCSUJ), 1990: The Syndicate of Journalists of the Czech Republic. (Ševčíková, 2015).

${ }^{9}$ The Revolutionary Trade Union Movement Act was passed on 16 May 1946. In 1947, the decision was taken that the CJU should also fulfil the function of a trade union. Divisional membership was voluntary; however, the CJU pointed out to its members that the CJU would not represent them in professional issues if they were not members of the Revolutionary Trade Union Movement. From 1 January 1948, the Agreement on the Entry of Journalists into the Revolutionary Trade Union Movement came into force and after that date, the majority of journalists joined a trade union.

10 Act No. 101/1974 Coll. It stipulated, among other things, who could become an editor, laid down the rights and responsibilities of editors, including the right of the Union to take disciplinary action against its members.
} 
ism as a profession and membership, meaning that the organization toed the Communist party line throughout its existence.

From 1948, the CJU and UCSJ also served as the gateway to international organizations, above all to the IOJ. In July 1968, following the events of the Prague Spring, the UCSJ held a landmark congress. A new statute and several resolutions were adopted in support of a new model of Socialism ("with a human face"), democracy and freedom of the press, speech and information. The former UCSJ was abolished and new Unions of Czech (UCJ, 19681972) and Slovak (USJ, 1968-1972) Journalists, including an umbrella organization (Headquarters, 1968-1972) were formed.

The new organizational model continued until August 1968. Both the Headquarters and UCJ were under the control of the Commission for the Preparation of the II Congress of the UCJ, which soon overturned all the decisions of the previous leadership and set up a cleansing commission on the basis of which 479 journalists were excluded from the Union and therefore also from their profession between September 1968 to March 1970, followed in 1972 by another 800 journalists.

As of 1971 the whole union had a complete overhaul in the line of normalization. In May 1972 a congress was convened at which the Czech Union of Journalists (CUJ, 1972-1990), the Slovak Union of Journalists (SUJ, 19721990) and the National Czechoslovak Union of Journalists (NCSUJ, 1972-1990) were established.

The big breakup of the NCSUJ took place at the turn of 1989 and 1990, due to the political events of the Velvet Revolution and the end of the Communist regime. Immediately after 17 November 1989, a new management of the CUJ, including the Bureau and its secretariat, was elected. At the same time, the new Bureau of the CUJ convened a general meeting on 16 December 1989, at which it was decided to create a new journalist organization, with the form of a syndicate. The old Union (CUJ) was dissolved at the extraordinary congress of the CUJ on 6 January 1990, and the successor organization became the Syndicate of Journalists of the Czech Republic, as a voluntary, independent, non-political, professionally united union of Czech and Moravian journalists. (Prouza, 1990) The new Syndicate refused to join the IOJ and instead became member of the IFJ.

\section{The IOJ from 1946 to the 1990 s}

\subsection{Founding and Split}

The IOJ was founded at the International Congress of Journalists in June 1946 in Copenhagen, the capital of Denmark, which had only recently been liberated from Nazi occupation. The congress was attended by 165 delegates ${ }^{11}$ from 21 countries. The post-war atmosphere was one of joy and optimism. In Czechoslovakia, this came just after the post-war parliamentary elections, which brought the Communists to power as the leading political force (for details of the first IOJ congresses, see Nordenstreng \& Kubka, 1988).

The provisional constitution was finalised and approved at the second IOJ congress held in Prague in June 1947 and attended by 208 delegates from 21 countries, the UN and UNESCO. The CJU, led by Jiři Hronek, was responsible for organizing the congress and its patron was President Edvard Beneš, who spoke at the opening ceremony, as did Jan Masaryk (Czechoslovak Minister of Foreign Affairs) and Klement Gottwald (Prime Minister and CPC Chairman).

The same positive atmosphere prevailed at the second congress in Prague as one year earlier in Copenhagen, although some tension about the impending division of the world could already be sensed. While the host union was in the middle of structural and political changes, the congress went smoothly in impressive settings. The constitutional statutes and principal resolutions were approved unanimously, likewise the leadership elected, with Archibald Kenyon of the UK continuing as President and Vice Presidents coming from the USA, USSR, France and Denmark. Hronek was unanimously elected to the combined office of Secretary General and Treasurer. But the site of the headquarters had to be put to a vote, the majority supporting Prague, while a minority led by British and Americans voted for London.

In less than a year after the Prague congress, by early 1948, the Cold War had broken out and a wave of political system changes in Central and Eastern Europe led to a division of Europe into East and West, separated by the "iron curtain". The IOJ was part of this battleground, becoming embroiled in Cold-War politics (Nordenstreng et al., 2016). The post-war unity of professional journalists was quickly replaced by distrust and antagonism between the capitalist West and the socialist East, exacerbated by political mobilization in both camps. Efforts by the Czech Secretary General Hronek and the British President Kenyon to hold the IOJ together were overruled by orders from Cold-War strategists in London and Washington, on the one hand, and the Soviet Communist Party hardliners in Moscow, on the other (Nordenstreng, in press).

The IOJ headquarters in Prague chose the Soviet side of the political divide as swiftly as the Czechoslovak Union was moved to the Socialist camp. These two processes were parallel and obviously reflections of a common overall shift in global relations of power.

In 1948-1949 the IOJ lost its West European and North American members, except for left-leaning groups of journalists there (mainly in France and Finland). The third IOJ congress in Helsinki in 1950 confirmed the change by changing the statutes in line with the Communist approach, the bulk of the membership in the Socialist countries of Central-Eastern Europe and newly inde-

\footnotetext{
11 The Czechoslovak delegation to the Congress was represented by CJU Chairman Otakar Wünsch, Jiří Hronek, K. F. Zieris (CJU secretary) and Emil Štefan (USJ).
} 
pendent countries of the Third World, including Communist China.

The IOJ had become one of the "democratic international organizations" closely associated with the USSR. The Western journalists' associations established a new International Federation of Journalists (IFJ) in Brussels in 1952-as part of the "Free West" countering the "Communist East". The Cold War politics led to the loss of the IOJ's affiliation with the UN and UNESCO, but it gained new members in the developing countries of Africa, Asia and Latin America. In 1966, its membership amounted to 130,000 journalists in 108 countries, while the IFJ had 55,000 members in 31 countries.

\subsection{The Prague Spring}

The IOJ continued to grow despite turmoil in its political environment caused by the Prague Spring in 1968 and its aftermath. The IOJ had its premises in the building of the Czechoslovak Union UCSJ, and in August 1968 the whole building was occupied by Warsaw pact forces. However, the IOJ was soon allowed to return to its premises and continued more or less as before, while the reformist Czechoslovak Union was effectively replaced by a new CJU (see above).

Unlike in 1948, the IOJ did not dramatically follow the system change implemented in the national union. Actually the IOJ activities, including the monthly publication The Democratic Journalist, had since the 1950s remained quite true to the "Moscow line", with no symptoms of the Prague Spring. By the 1970s the IOJ was firmly consolidated on the basis established in the late 1940s, now increasingly dominated by an "anti-imperialist" orientation reflecting the concerns of the developing countries and meeting the Soviet interests. The changing climate of international relations was also instrumental to reinstating IOJ's affiliation with the UN and UNESCO.

Financial support for more and more activities around the world came not only from the nominal membership fees but from public "solidarity lotteries" in East European Socialist countries. Moreover, a peculiar source for financing was invented by new Secretary General Jiři Kubka together with the Hungarian Treasurer Norbert Siklósi: the IOJ was permitted, with the blessing of the Communist Party, to establish commercial companies in translation and conference services, publishing, etc. This privilege made the IOJ quite rich, facilitating a large secretariat with a publishing house, training schools in European Socialist counties, regional centres on all developing continents and large conferences around the world.

The heyday of the IOJ was in the late 1980s, when its membership reached 300,000 . By this time its political line had become much more open and broad, particularly by its active engagement in East-West détente from 1973 on, leading gradually to contacts and even cooperation with the IFJ in the 1980s (Nordenstreng et al., 2016).

\subsection{The Velvet Revolution}

The Cold War world order began to crumble in late 1989, when first the Berlin Wall fell and then Prague was shaken by the Velvet Revolution, followed by the fall of Communism in Eastern Europe. Global geopolitics was suddenly changed and the IOJ was challenged: its headquarters and operations in Prague came under sharp attack from the rising political forces in Czechoslovakia, and its local member Union-the legal base for its seat in Prague-was closed down and replaced by a new Syndicate which did not want to affiliate with the IOJ but joined the IFJ. Moreover, other strong member unions in former Socialist countries, notably the USSR, began to lose political and material ground. The IOJ's financial resources were rapidly dwindling and activities in training, publication, etc. were gradually discontinued.

Nevertheless, in 1991 the IOJ held its 11th congress in Harare in fairly good shape, but by its 12 th congress in Amman in 1995 it was crippled by shrinking finances and quarrelling leadership. After this, member unions one after another decided to join the IFJ, while most of them also remained nominal members of the IOJ. By the end of the 1990s the IOJ had in fact disappeared from the scene, whereas the IFJ had grown into an organization also representing the bulk of the earlier IOJ membership. Finally, in 2016, the last two IOJ presidents pronounced the IOJ effectively dead (Nordenstreng, in press).

\section{Conclusion}

In summary: (1) the system change in 1948 from liberal democracy to Communism in Czechoslovakia immediately involved journalists with their national association, and the IOJ followed suit driven by the same developments among all the Soviet-dominated Eastern European member associations, while the Western members withdrew without an organizational fight; (2) the system instability of 1968 with an attempt to liberalize Communism hit the national association hard but did not extend to the IOJ, which continued largely unchanged; (3) the system change in 1989 caused an immediate upheaval in the national association and the gradual disintegration of the IOJ, again as a result of changes throughout the Soviet block-a reverse process of 1948.

The story of Czechoslovak journalist organizations and the IOJ adds further evidence to the overall lesson presented in Nordenstreng et al. (2016, p. 180): international journalists' associations are invariably bound by their political environments and to believe that journalists and their associations can ever be completely apolitical is a naïve illusion. However, the international movement is not deterministically driven by politics alone; it is also driven by professional interests with more or less autonomy.

This article has mostly concerned the political history of Czechoslovakia, which already suggests another general conclusion: in order to understand the relationship 
which the media and journalists, including their associations, have to political system changes, it is vital to have a profound knowledge of the history of the country in question. All too often are changes in media and journalists studied with a superficial understanding of the historical context.

\section{Acknowledgments}

The authors wish to thank Isabel Stainsby and Virginia Mattila for their assistance in checking the English of this article.

\section{Conflict of Interests}

The authors declare no conflict of interests.

\section{References}

Cebe, J. (2012). Novinářská organizace v letech 19451948 [Journalists organization 1945-1948] (Unpublished Doctoral dissertation). Charles University, Prague, Czech Republic.

Cebe, J. (2017). Cleansing among Czech journalists after World War II and a comparison with the situation in France and the Netherlands. Media and Communication, 5(3), 70-78.

Drápala, M. (2000). Na ztracené vartě Západu: antologie české nesocialistické publicistiky z let 1945-1948 [The lost guard of the West: An anthology of Czech non-Socialist journalism from 1945-1948]. Prague: Prostor.

Emmert, F. (2012). Průvodce českými dějinami 20. století [A guide to Czech history of the 20th century]. Brno: Clio.

\section{About the Authors}

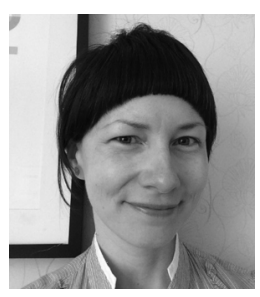

Markéta Ševčíková is an independent researcher in the field of media history from Prague, Czech Republic. Her research focuses mainly on Czechoslovak journalists and the International Organization of Journalists. She studied at the Charles University, Faculty of Humanities and Faculty of Social Sciences. She has worked as a media analyst, freelance editor and a PR specialist in commercial and non-governmental organizations.

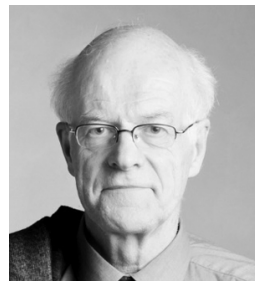

Kaarle Nordenstreng is Professor Emeritus of Journalism and Mass Communication at the University of Tampere, Finland. He worked as a freelance journalist starting in the mid-1950s and served as head of research in the Finnish Broadcasting Company in the late 1960s. His research has focused on theories of communication and global media. He has been Vice President of the International Association for Mass Communication Research (IAMCR, 1972-1988) and President of the International Organization of Journalists (IOJ, 1976-1990). For more, see http://www.uta.fi/cmt/en/contact/staff/ kaarlenordenstreng/index.html 